\title{
CORRESPONDENCE
}

\section{On the beerbachites from Freetown, Sierra Leone}

SIR - The origin of a finely equigranular plagioclasehypersthene-clinopyroxene-magnetite/ilmenite rock suite found within the layered basic (gabbroic) intrusion of Freetown, Sierra Leone (Fig. 1) has long been discussed. This peculiar rock type with mosaic or saccharoidal texture has been given various names which depend on views of the origin of beerbachite (Chelius, 1892) from the gabbro massif in Odenwald, Germany. The early view was that the Odenwald beerbachite is igneous (Chelius, 1892; Rosenbusch, 1901). More recently, however, it has been shown that the beerbachite is a highly metamorphosed xenolithic country rock enclosed within the Odenwald gabbroic intrusion (Klemm, 1927; Trochim, unpub. thesis, Univ, Freiburg, 1960; Matthes \& Schubert, 1971). By this a recognition is made of the much wider significance of distinguishing igneous from metamorphic textures in high grade basic rocks.

Shand (1918) identified 'a fine-grained melanocratic suite with equigranular crystals' in the Freetown intrusion, which he named ('micro norite or trap granulite'. This rock suite was later named beerbachite by Dixey (1922) who considered that it was of intrusive igneous origin, emplaced into the layered gabbro. Both Junner (1929) and Pollett (1951) held the same view.

Wells (1962) first recognized that the granular suite is xenolithic and that its texture is granoblastic. He identified it as a hornfels, and named it a granulite, restricting the term beerbachite to pseudo-dyke forms. He thought that earlier layered gabbro became recrystallized during subsequent magma pulses of the multiple intrusion and that the 'granulite' was concentrated near the contact horizons of the main zones (Wells, 1962, p. 83).

In this report the gross features that bear on the origin of this peculiar granular suite of rocks are shown and its name is given.

\section{Association and description of the participating rocks}

1.a. The basement complex

The country rocks are metasediments and metavolcanics with a late Precambrian Pan-African $(600 \pm 150 \mathrm{Ma})$ history (Kennedy, 1964; Hurley et al. 1971). Amphibolites and hornblende gneisses predominate, and attained amphibolite

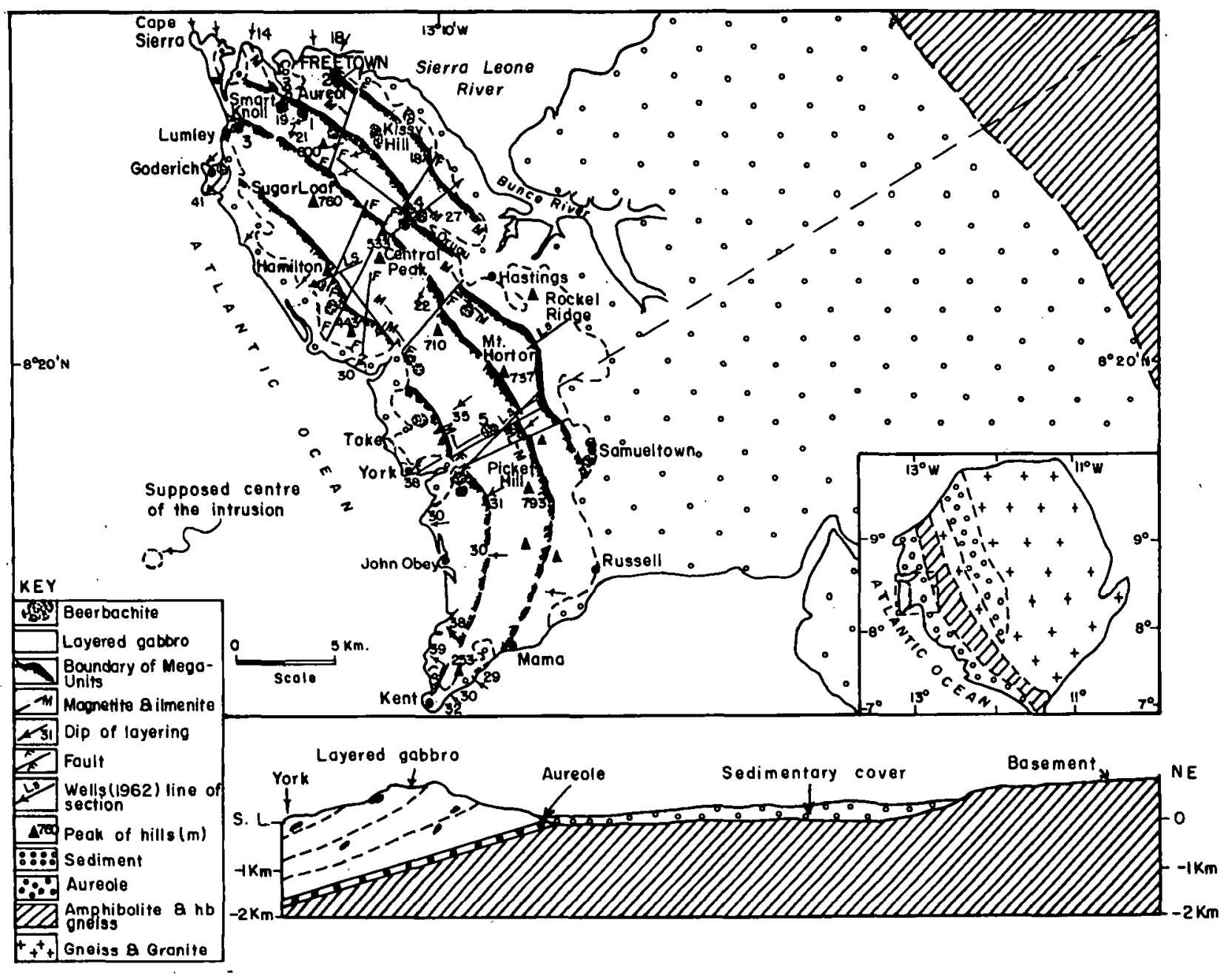

Figure 1. Geological map of and section across the peninsula area of Freetown. 
Table 1. Modal analysis of some of the beerbachites

\begin{tabular}{|c|c|c|c|c|c|c|c|c|c|}
\hline $\begin{array}{l}\text { Serial No.... } \\
\text { Sample No... }\end{array}$ & $\begin{array}{c}1 \\
166\end{array}$ & $\begin{array}{c}2 \\
309\end{array}$ & $\stackrel{3}{393}$ & $\begin{array}{c}4 \\
903\end{array}$ & $\underset{523}{5}$ & $\begin{array}{c}6 \\
635\end{array}$ & $\begin{array}{c}7 \\
670\end{array}$ & $\begin{array}{c}8 \\
269\end{array}$ & $\begin{array}{c}9 \\
962\end{array}$ \\
\hline Plagioclase & 51.4 & 58.0 & 55.8 & 62.5 & 58.2 & 48.0 & 45.6 & 57.0 & 54.0 \\
\hline Hypersthene & 28.6 & 18.2 & 26.3 & 14.9 & 19.2 & 10.0 & 15.4 & 22.0 & 23.0 \\
\hline Clinopyroxene & 17.3 & 21.5 & 15.0 & 16.5 & 17.5 & 30.0 & 24.5 & 18.5 & 19.5 \\
\hline Ilmenomagnetite & 2.4 & 2.3 & 2.8 & 6.0 & 4.8 & 12.0 & 14.0 & 2.5 & 3.5 \\
\hline Others & 0.3 & - & 0.1 & 0.1 & 0.3 & - & 0.5 & - & - \\
\hline Total & 100.0 & 100.0 & 100.0 & 100.0 & 100.0 & 100.0 & 100.0 & 100.0 & 100.0 \\
\hline
\end{tabular}

1. Smart Knoll; 2. Mount Aureol; 3. Lumley Road Station; 4. W of Orugu River; 5. Big Water; 6. Big Water; 7. Banana Island; 8. Kissy Spur; 9. Spike Hill.

facies metamorphism. They are composed of plagioclase $\left(A n_{27-30}\right)$, green hornblende, biotite, quartz and, occasionally, garnet with zircon, sphene and epidote as accessory minerals.

\section{1.b. Layered gabbro}

The Freetown basic magma was emplaced in the basement complex of Sierra Leone (Fig. 1) during the Triassic (Briden, Henthorn \& Rex, 1971) as repetitive magma pulses (Wells, 1962). Olivine and ilmenomagnetite-rich layers (dunite, troctolite and olivine gabbro) occur in the lower part, and plagioclase-rich layers (leuco-gabbro and anorthosite) in the upper part (Umeji, 1975, 1983). Five fully developed layered successions have been recognized as mega-units (Fig. 1) but several miniature units have been mapped within each of them (Wells, 1962; Umeji, 1983). The intrusion is circular or elliptical in outline and the dips are towards the centre which is located to the west of York (Junner, 1929; Baker \& Bott, 1961; Wells, 1962; Krause, 1963). The dips of the layered rocks vary from $14^{\circ}-22^{\circ}$ near the outer margin to $30^{\circ}-45^{\circ}$ near the centre (Fig. 1), and the thickness of the sequence is about $6 \mathrm{~km}$.

\section{1.c. Contact aureole: hornblende hornfelses}

The boundary between the intrusion and the host basement complex is concealed beneath a thick cover of younger sediments (Fig. 1). Samples of the aureole have, however, been obtained from borings through the sediments and the supposed contact (Geological Survey of Sierra Leone Annual Reports, 1956, 1957). The borehole near Rokel passed through about $500 \mathrm{~m}$ of hornblende hornfels into unrecrystallized country rock.

In the outer part of the aureole, the hornfels consists of plagioclase $\mathrm{An}_{35-42}$, green hornblende, clinopyroxene, biotite and poikiloblastic hypersthene whilst magnetite, apatite and sphene occur as accessory minerals. Adjacent to the layered gabbro, the hornfels becomes more granoblastic and is composed of plagioclase $\mathrm{An}_{48-50}$, clinopyroxene, hypersthene and greenish-brown hornblende with magnetite/ilmenite, apatite and sometimes biotite in accessory amounts. In this inner aureole, plagioclase is finely mosaic and hypersthene is granoblastic and poikiloblastic, enclosing flakes of green biotite, and grains of hornblende.

\section{1.d. Beerbachites: hypersthene hornfels xenoliths}

Nowhere is the roof of the Freetown intrusion preserved but xenoliths occur sporadically throughout. The locations of xenoliths shown in Figure 1 are concentrated in parts of the

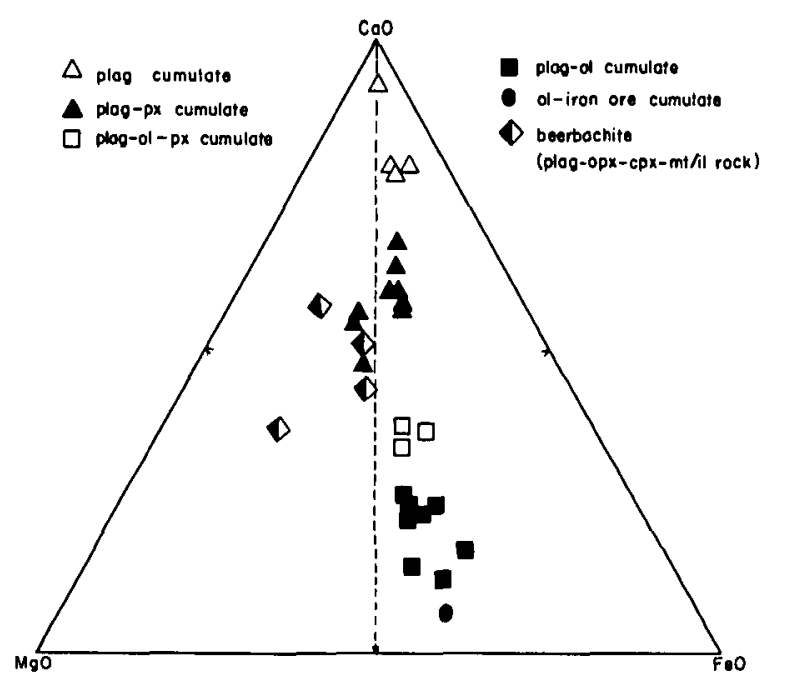

Figure 2. $\mathrm{CaO}-\mathrm{MgO}-\mathrm{FeO}$ diagram for Freetown layered gabbro and enclosed beerbachites. Broken line separates beerbachites and contaminated gabbro from the trend of the layered igneous rocks. (Data from Umeji, 1983).

central and the northern portions of the intrusions but this may reflect the fact that only these areas were well mapped. The xenoliths range from lenses a few centimetres long and about a centimetre thick to large masses up to $300 \mathrm{~m}$ long, $150 \mathrm{~m}$ wide and $5 \mathrm{~m}$ thick. Of over sixty outcrops visited, there are only two areas in which the outcrops are steeply inclined and apparently wedge across the layered gabbro. The rest are flat-lying, more or less paralleling the layering of the host gabbro. In all cases, the xenoliths have sharp and irregular contacts with the gabbros and no chilled margin has been observed. Occasionally a porphyroblastic or pegmatitic texture is developed at the margin of the xenoliths.

The xenoliths are distinctively dark with a fine-grained granoblastic texture, usually equigranular. They are composed of plagioclase $\mathrm{An}_{55-64}$, hypersthene, clinopyroxene and some magnetite and/or ilmenite. The modes of xenoliths are given in Table 1. Magnetite and ilmenite are often more abundant in these rocks than in the host layered rocks. Olivine and hornblende are invariably absent, but retrogressive biotite may occur. A case in which biotite originating from layered gabbro grew across the contact into beerbachite was reported by Wells (1962, p. 94 and fig. 34a). Normally the size of mineral grains depends on the size of the xenolithic body. For very small bodies the mineral grain size can be as little as $0.05 \mathrm{~mm}$ across, but the larger masses are composed of minerals whose average diameter is about 


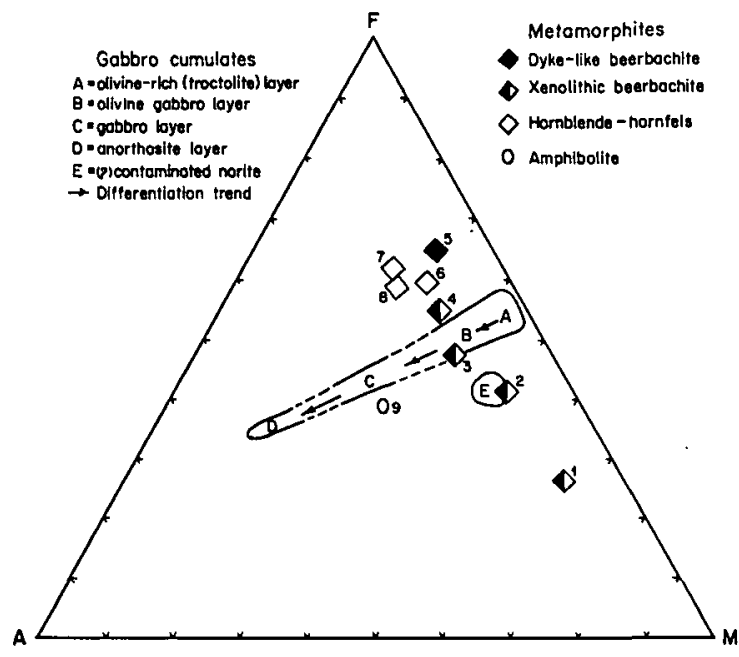

Figure 3. Plot of the Freetown beerbachites and hornblende hornfels in the AFM diagram of the Freetown layered gabbro (cf. Umeji, 1983, fig. 6). Locations for 1-5 are shown in Figure 1; 6-9 are borehole samples of the aureole. Data for 1 and 2 are from Umeji (1983) and for 3-9 from Wells (1962).

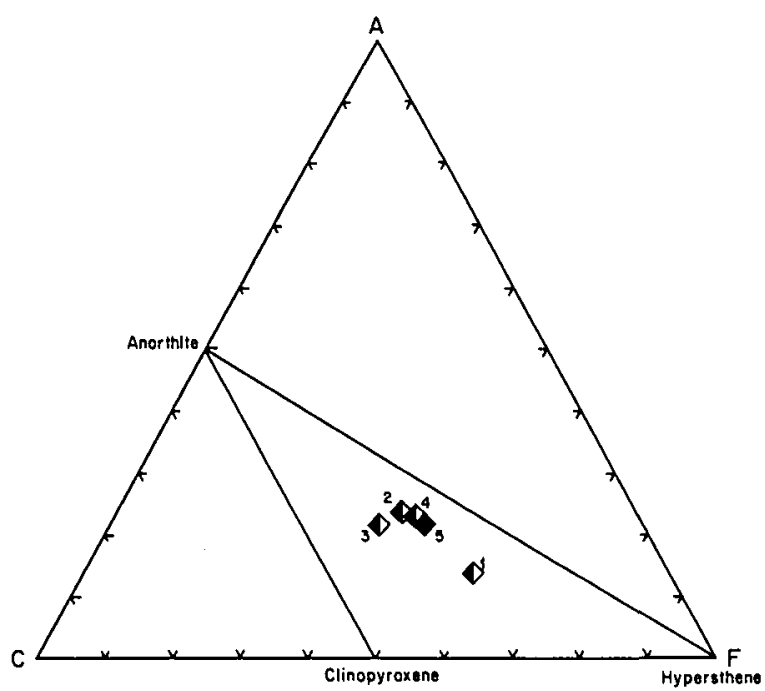

Figure 4. Plot of the Freetown beerbachites on an ACF diagram (after Winkler, 1979). Symbols and numbers are as in Figure 3.

$0.5 \mathrm{~mm}$. The marginal pegmatites around equigranular xenoliths are rich in porphyroblastic pyroxenes, and magnetite and/or ilmenite which approach the size of the minerals in the layered gabbro $(1-2.5 \mathrm{~mm})$. In the gabbro, fine-grained layers have plagioclase $1.5 \mathrm{~mm}$ long and $0.5 \mathrm{~mm}$ across and in the coarse-grained layers it reaches $4.5 \mathrm{~mm}$ by $1.5 \mathrm{~mm}$. The opaque phases, and to a lesser extent the pyroxenes, in the marginal pegmatites of the xenoliths are characterized by sieve or skeletal texture. All the xenolithic rocks found may be assigned to the pyroxene hornfels facies.

\section{Chemical, genetic and phase relations}

\section{2.a. Chemical characteristics and genetic relations}

Published analytical data (Junner, 1929, p. 426; Wells, 1962, tables 7, 8 and 9; Umeji, 1983 table 1) are used in the present paper. It will be seen from the $\mathrm{CaO}-\mathrm{MgO}-\mathrm{Feo}$ diagram (Fig. 2) that beerbachites and a few hybrid gabbroic rocks plot away from the trend of differentiation shown by normal gabbro cumulates. Similarly the beerbachites and hornblende hornfelses of the contact zone do not plot within the area of the cumulate rocks in the AFM triangular diagram (Fig. 3). Some of the coarse-grained noritic rocks within the layered rocks seem to be contaminated by the country rock. $\mathrm{Sr}$ is lower in the beerbachites (169.8-192.6 ppm) than in norites and gabbros of the layered sequence (381.6-605.7 ppm). It had been shown that in the layered gabbro intrusion the abundances of $\mathrm{Sr}$ and $\mathrm{Ni}$ are related to the amounts of Al-silicate (plagioclase) and $\mathrm{Mg}$-silicates (olivine/pyroxenes) respectively, and the positive correlation of $\mathrm{Ni}$ vs. $\mathrm{MgO}$ and $\mathrm{Sr}$ vs. $\mathrm{Al}_{2} \mathrm{O}_{3}$ shows that the layered rocks are cumulates from the same parent magma (Umeji, 1983). The indication is that these beerbachites are not genetically related to the layered rocks. The bulk of hornfelsic rocks (beerbachites and hornblende hornfelses) are seen (Figs. 2 and 3) to be derived from the country rocks rather than from the gabbros. It is also observed that the hornblende hornfelses plot with beerbachite on Figure 3 .

\section{2.b. Mineral reactions}

In the aureole surrounding the intrusion garnet is no longer stable and according to Krogh (1982, p. 313) garnet breaks down to green hornblende + magnetite or to plagioclase + biotite + magnetite while rutile breaks down to ilmenite at temperatures in excess of about $700^{\circ} \mathrm{C}$. With increasing dehydration and metamorphic grade, quartz and hornblende disappeared and hypersthene and the anorthite content of plagioclase increased in the beerbachites. The latter (see Fig. 4) attained the pyroxene-hornfels facies (Eskola, in Barth, Correns \& Eskola, 1939, p. 344; Turner, 1981). The mineral reactions may also be explained by some of the following:

$$
\begin{array}{cc}
\mathrm{nCa}(\mathrm{Mg}, \mathrm{Fe})_{2} \mathrm{Al}_{2} \mathrm{Si}_{3} \mathrm{O}_{12} & +\mathrm{SiO}_{2} \\
\text { garnet } & \text { quartz } \\
& =\mathrm{CaAl}_{2} \mathrm{Si}_{2} \mathrm{O}_{8}+2(\mathrm{Mg}, \mathrm{Fe}) \mathrm{SiO}_{3},
\end{array}
$$

$\mathrm{NaCa}_{2}\left(\mathrm{Si}_{7} \mathrm{Al}\right) \mathrm{O}_{22}(\mathrm{OH})_{2}+\mathrm{SiO}_{2}$

'edenitic' hornblende quartz

$$
=\underset{\text { albite }}{\mathrm{NaAlSi}_{3} \mathrm{O}_{8}}+\underset{\text { diopside }}{2 \mathrm{CaMgSi}_{2} \mathrm{O}_{6}}+\underset{\text { hypersthene }}{3 \mathrm{MgSiO}_{3}}+\mathrm{H}_{2} \mathrm{O},
$$

$\mathrm{Ca}_{2}\left(\mathrm{Mg}_{4} \mathrm{Al}\right)\left(\mathrm{Si}_{7} \mathrm{Al}\right) \mathrm{O}_{22}(\mathrm{OH})_{2}$

'tschermakitic' hornblende

$$
=\underset{\text { anorthite }}{\mathrm{CaAl}_{2} \mathrm{Si}_{2} \mathrm{O}_{8}}+\underset{\mathrm{CaMgSi}_{2} \mathrm{O}_{6}}{\mathrm{Capside}_{\text {hypersthene }}}+3 \mathrm{MgSiO}_{3}+\mathrm{H}_{2} \mathrm{O} .
$$

The amphibole substitutions involved here are the 'edenite' substitution $\square \mathrm{Si}=\mathrm{NaAl}$; and the 'tschermakite' substitution $\mathrm{MgSi}=\mathrm{AlAl}$.

\section{Causes of metamorphism and temperature-pressure distribution}

The regionally metamorphosed country rocks of western Sierra Leone (Rollinson, 1982) were essentially cool before they were intruded by gabbro about $350 \mathrm{Ma}$ after the climax of the Pan-African thermotectonism; hence the presence of a distinct hornfelsic aureole around the intrusion. The intrusion is believed to be associated with the opening of the North Atlantic which began its latest cycle about $200 \mathrm{Ma}$ (Klein, 1969; Kaye, 1983). Transform fault/fracture zones intersecting with the Sierra Leone coastline (Williams \& Williams, 1977) must have been developed during the Trassic 
rifting apart of North America from Africa/South America whose onset created fault-bounded late Triassic volcanosedimentary basins of the eastern coast of the U.S.A. (Klein, 1969). Similar fault-controlled magmatism of late Triassic age has been identified in this part of West Africa. One example is the coast-parallel dykes of Liberia (Dalrymple, Gromme \& White, 1975), and the Freetown layered gabbro on the coast of Sierra Leone is regarded as another (cf. Williams \& Williams, 1977). The Freetown gabbro was therefore emplaced anorogenically. The original depth of burial is thought to be shallower than $9 \mathrm{~km}$ corresponding to a pressure of around $2.5 \mathrm{kbar}$.

A gabbroic magma intruding at a temperature of $1200^{\circ} \mathrm{C}$ (liquidus) would possess a maximum possible contact temperature of $1000^{\circ} \mathrm{C}$ (solidus), above which remelting could begin. The estimated contact metamorphic conditions for the country rock hornfelses of Freetown are comparable with those of the contact aureoles around the Newer intrusions of the southern Scottish Highlands (Ashworth \& Chinner, 1978) and of the Nain anorthosite body, Labrador (Bohlen \& Boettcher, 1981) whose respective estimates are temperatures of $690^{\circ} \mathrm{C}$ and $750-800^{\circ} \mathrm{C}$ and pressures of $3.8 \mathrm{kbar}$ and $3.2 \mathrm{kbar}$. Greater depths of equilibruim with pressures of 4-15 kbar estimated from granulite facies metamorphism (e.g. Miyashiro 1961; Grew, 1980; Perkins \& Newton, 1981) may not be applicable; this is because contact metamorphic rocks, as considered here, are products of low pressures.

The thickness of the aureole $(500 \mathrm{~m})$ is in reasonable agreement with that of an intrusion about $1500 \mathrm{~m}$ thick judging from Jaeger's (1957) estimate. A much thicker aureole could have emerged were the $6000 \mathrm{~m}$ thick gabbro a product of a single batch of magma. The size of the hornfelsic aureole will serve as further evidence for emplacement of discrete batches of magma into Freetown crust. Using equations 9 and 10 of Jaeger (1968) and numerical values given in his tables I and II it can be shown that the cooling or solidification time for the initial intrusion, assumed to be $1500 \mathrm{~m}$ thick, would be about 3600 years. This assumes a sheetlike body, without convection, cooling against the country rock whose initial temperature is taken as zero. Jaeger (1968) also made calculations to simulate convection (formulae 58-62) and showed that convection in a sheetlike body $1000 \mathrm{~m}$ thick intruded at a temperature of $1225^{\circ} \mathrm{C}$ would have the value of $1000{ }^{\circ} \mathrm{C}$ after a time of 4000 years. At the contacts of the Freetown magma, in which evidence for convection abounds (Wells, 1962; Umeji, 1975), a temperature of $1000^{\circ} \mathrm{C}$ would be retained for a period of well over 4000 years for, at least, the first magma pulse. The large quantity of heat conducted into the country rock for this long period of time would be adequate for contact metamorphic recrystallization.

In the hornfelsed country rocks, the temperature did not exceed the stability limit for hornblende. This confirms the low temperature of the country rocks prior to intrusion. However, small bodies of country rock that stoped off, and became entirely immersed in Freetown magma, became raised to magmatic temperatures and hence produced a higher temperature assemblage than the surrounding hornfelses. In xenoliths, therefore, the temperature exceeded the stability limit for hornblende. Convection in the magma and an intermittent or pulsating intrusive mechanism would help in the production and redistribution of xenoliths. It is significant that no sign of contact metamorphic overprinting has been observed within the layered sequence due to fresh magma intruding.

\section{Conclusions}

The following conclusions are drawn:

(1) A prograde thermal metamorphism is recognized at the contact of the Freetown basic intrusion with the basement, and hornblende hornfelses occur at the inner aureole.

(2) The fine-grained plagioclase-hypersthene-clinopyroxene-magnetite/ilmenite rocks characterized by mosaic texture are rafts or blocks torn off the surrounding country rocks. They are xenoliths which were thermally recrystalized to pyroxene hornfels facies by the hot gabbroic magma. No transition from the gabbros to the xenoliths has been observed and the xenoliths are not restricted to the boundary between two layered units; therefore the xenoliths are not cognate masses derived from the gabbroic host as suspected by Wells $(1962$, p. 81$)$. This conclusion is supported by geochemical considerations.

(3) It is now known that the beerbachites of Odenwald, Germany are highly metamorphosed rock older than the gabbro in that area (Klemm, 1927; Trochim, 1960), that they are xenoliths from surrounding amphibolite series and that they are high grade hornfelses (Matthes \& Schubert, 1971). The observed conditions under which the Freetown granular rocks were formed are similar to those of Odenwald. The plot of the Freetown beerbachite suite on an ACF diagram (Fig. 4) compares well with the high grade of Odenwald (Matthes \& Schubert, 1971, fig. 13), which reached the pyroxene hornfels facies. The name beerbachite given to this suite of rock from Freetown (Dixey, 1922) should therefore be retained because it is similar in texture, mineralogy, facies grade and origin to the Odenwald beerbachite suite.

(4) Metamorphosed basic rocks recrystallized at magmatic temperatures can be distinguished from primary gabbros by granoblastic texture in the former. The beerbachite consists of a mosaic of xenoblastic mineral grains, commonly equigranular. The interpretation of such relations thus differs fundamentally from that of grabbros in which euhedral character is determined by order of crystallization.

\section{References}

Ashworth, J. R. \& Chinner, G. A. 1978. Coexisting garnet and cordierite in migmatites from the Scottish Caledonides. Contributions to Mineralogy and Petrology 65, 379-94.

BAKER, C. O. \& BotT, M. H. P. 1961. A gravity survey over the Freetown basic complex of Sierra Leone. Overseas Geology and Mineral Resources 8 (3), 260-78.

Barth, T. F. W., Correns, W. C. \& Eskola, P. 1939. Die Entstehung der Gesteine. Berlin: Springer-Verlag.

Bohlen, S. R. \& BoetTCher, A. L. 1981. Experimental investigations and geological applications of orthopyroxene geobarometry. American Mineralogist 66 951-64.

Briden, J. C., Henthorn, D. I. \& Rex, D. C. 1971. Palaeomagnetic and radiometric evidence for the age of the Freetown igneous complex, Sierra Leone. Earth and Planetary Sciences Letters 12, 385-91.

Cheluus, C. 1892. Das Granitmassiv des Melibocus und seins Ganggesteine. Notizblatt der Vereinigung Erdkunde Darmstadt, Series 4, part 13, 1-13.

Dalrymple, G. B., Gromme, C. S. \& White, R. W. 1975. Potassium-argon age and paleomagnetism of diabase 
dykes in Liberia: initiation of central Atlantic rifting. Bulletin of the Geological Society of America 86, 399-441.

Dixey, F. 1922. The norite of Sierra Leone. Quarterly Journal of the Geological Society of London 78, 299-343.

Geological Survey OF SierRa LeONe. 1956. Progress report on SLBH near Samueltown. Annual Report for 1956.

Geological Survey OF SierRa LeONE. 1957. Progress report on SLBH near Rokell. Annual Report for 1957.

Grew, E. S. 1980. Sillimanite and ilmenite from high-grade metamorphic rocks of Antarctica and other areas. Journal of Petrology 21, 39-68.

Hurley, P. M., Leo, G. W., White, R. W. \& Fairbairn, H. W. 1971. Liberian age province (about $2700 \mathrm{~m} . \mathrm{y}$.) and adjacent provinces in Liberia and Sierra Leone. Bulletin of the Geological Society of America 82, 3483-90.

JAEGER, J. C. 1957. The temperature in the neighbourhood of a cooling intrusive sheet. American Journal of Science 255, 306-18.

JAEGER, J. C. 1968. Cooling and solidification of igneous rocks. In Basalts: The Poldervaart Treastise on Rocks of Basaltic Composition, vol. 2 (ed. H. H. Hess), pp. 503-36. Wiley Interscience.

JunNER, N. R. 1929. The norite of Sierra Leone, British West Africa. Report of the 15th Session of the International Geological Congress, South Africa 2, 417-33.

KAYE, C. A. 1983. Discovery of a Late Triassic basin north of Boston and some implications as to post-Paleozoic tectonics in northeastern Massachusetts. American Journal of Science 283, 1060-79.

KENNEDY, W. Q. 1964. The structural differentiation of Africa in the Pan-African ( \pm 500 m.y.) tectonic episode. Annual Report of the Research Institute for African Geology, University of Leeds 8, 48-9.

KLEIN, G. DE V. 1969. Deposition of Triassic sedimentary rocks in separate basins, eastern North America. Bulletin of the Geological Society of America. 80, 1825-32.

KLEMM, G. 1927. Uber die sog. 'Gabbroaplite (Beerbachite)' des Odenwaldes. Notizblatt der Vereinigung Erdkunde Hessische Geologische Landesamt, Darmstadt V. Folge, H. 9. 111-5.

KraUSE, D. C. 1963. Seaward extension and origin of the Freetown layered basic complex of Sierra Leone. Nature 200, 1280-1.

KROGH, E. J. 1982. Metamorphic evolution of Norwegian country-rock eclogites, as deduced from mineral inclusions and compositional zoning in garnets. Lithos $15,305-21$.

MATthes, S. \& Schubert, W. 1971. Der original Beerbachit in Odenwald, ein Amphibolit-Hornfels in PyroxenHornfels-fazies. Contributions to Mineralogy and Petro$\log y 33,62-86$.

MiYashiro, A. 1961. Evolution of metamorphic belts. Journal of Petrology 2, 277-311.

Perkins III, D. \& Newton, R. C. 1981. Charnockite geobarometers based on coexisting garnet-pyroxeneplagioclase-quartz. Nature 292, 144-8.

PolletT, J. D. 1951. The geology and mineral resources of Sierra Leone. Colonial Geology and Mineral Resources 2, 3-28.

Rollinson, H. R. 1982. P-T conditions in coeval greenstone belts and granulites from the Archaean of Sierra Leone. Earth and Planetary Science Letters 59, 177-91.

RosenbuSCH, H. 1901. Analysis of beerbachite, Frankenstein, Odenwald. In Element der Gesteinslehre, p. 228. Stuttgart: Schweizerbart'sche Verlagsbuchhandlung.

Shand, S. J. 1918. The norite of the Sierra Leone. Geological Magazine 55, 21-3.

Turner, F. J. 1981. Metamorphic Petrology, 2nd ed. New York: McGraw-Hill.

UMEJI, A. C. 1975. Gravity stratification in the Freetown basic igneous layered complex, Sierra Leone, West Africa. Geological Journal 10, 107-30.

UmEI, A. C. 1983. Geochemistry and mineralogy of the Freetown layered basic igneous complex of Sierra Leone. Chemical Geology 39, 17-38.

Wells, M. K. 1962. Structure and petrology of the Freetown layered basic complex of Sierra Leone. Overseas Geology and Mineral Resources Bulletin, Supplement No. 4, 115 pp.

Williams, H. R. \& Williàms, R. A. 1977. Kimberlites and plate-tectonics in West Africa. Nature 270, 507-8.

WINKLER, H. G. F. 1979. Petrogenesis of Metamorphic Rocks, 5 th ed. New York: Springer-Verlag, 348 pp.

\section{A. C. UMEJI}

Department of Geology

University of Nigeria

Nsukka, Nigeria

14 May 1985 